\title{
МОТИВАЦІЯ ДО НАВЧАННЯ - ЗАПОРУКА ЕФЕКТИВНОСТІ СУЧАСНОЇ МЕДИЧНОЇ ОСВІТИ
}

\author{
I. V. Baranova, I. A. Iliuk, K. P. Postovitenko \\ M. Pyrohov Vinnytsia National Medical University \\ MOTIVATION TO STUDY IS A KEY TO THE EFFECTIVENESS OF \\ MODERN MEDICAL EDUCATION
}

\begin{abstract}
Анотація. У статті проаналізовано зовнішню та внутрішню складові мотивації до навчального процесу у студентів-медиків 5 курсу; розроблено рекомендації щодо вдосконалення викладання предметів у вищих навчальних закладах (ВН3) медичного профілю.

Наведено аналіз даних психодіагностичних тестів вивчення загальних мотивів навчальної діяльності у вітчизняних та іноземних студентів медичного ВНЗ. Висвітлено основні напрямки педагогічної діяльності, які сприяють зростанню зацікавленості студента та його активної участі у набутті теоретичних знань та практичних навичок.

Мотивація до навчання у вітчизняних та іноземних студентів відповідає середньому та високому рівням, бажання стати висококваліфікованим спеціалістом є пріоритетним у набутті знань. Використання новітніх інформаційних технологій, прийомів «ділової гри» та симуляційних центрів дозволяє ефективно підтримувати високий рівень науково-практичної підготовки майбутніх лікарів.
\end{abstract}

Ключові слова: мотивація; психодіагностичні тести; інформаційні технології; метод симуляції.

Abstract. The article analyzes external and internal motivational constituents to the educational process for the $5^{\text {th }}$ year studentsphysicians; development of recommendation is in relation to perfection of teaching of subjectss in medical schools.

The article adduces the analysis over of these psychodiagnostic tests of study of general reasons of educational activity for the home and foreign students of medical schools; describes the basic directions of pedagogical activity, that assist the increase of the personal interest of student and his active participation in acquisition of theoretical knowledge and practical skills.

Motivation to the studies in home and foreign students answers middle and high levels, desire to become a highly skilled specialist there is a priority in acquisition of knowledge. The use of the newest information technologies, receptions of "business game" and simulation centers allow effectively to support the high level of research and practice training of future doctors.

Key words: motivation; psychodiagnostics tests; information technologies; method of simulation.

Вступ. Одним із ключових завдань сучасної вищої освіти є підготовка спеціалістів з високим рівнем професіональної компетентності та різнобічним розвитком особистості, які здатні до постійного самовдосконалення [4, 13]. Високі особисті якості лікаря забезпечують комфортний психологічний контакт із хворим та підтримують самовідданість у професійній діяльності. Комунікативна компетентність є предметом спеціальних досліджень у галузі професійної підготовки майбутніх

(C) І. В. Баранова, І. А. Ільюк, К. П. Постовітенко лікарів (С. Герасименко, Ю. Ємельянова, С. Чусовлянова). Професійне спілкування вважається однією зі складових загальної культури відносин та сприяє успішній кар’єрі фахівця будь-якого напрямку діяльності [8, 9].

Проблема формування та підтримки зацікавленості навчанням та майбутньою професією у студентів ВНЗ медичного профілю продовжує існувати. Мотиваційні складові та фактори, які впливають на професійний та особистий розвиток лікаря, зростають із кожним курсом навчання, та цей про- 
цес не повинен зупинятися протягом всього життя [12, 14]. Багато науковців (Л. В. Беш, Б. Я. Дмитришин, О. М. Беш, О. І. Мацюра, С. С. Занюк та ін.) дослідили та впровадили у практику сучасні аспекти навчальної діяльності, які постійно продовжують доповнюватися та оновлюватись.

Наявність або відсутність у студентів сформованих позитивних мотивів здійснюють значний вплив на навчальну діяльність. Недостатня мотивація не може сприяти формуванню високої професійної реалізації студента [6]. Отже, відверте наполегливе бажання отримати знання та навички має стати відправною точкою у формуванні високопрофесійного спеціаліста медичної галузі [2].

Мета дослідження - вивчення особливостей мотивації до навчального процесу студентів 5 курсу медичного факультету Вінницького національного медичного університету ім М. І. Пирогова та розробка рекомендацій щодо її вдосконалення.

Методи дослідження. У дослідженні брали участь 94 студенти 5 курсу медичного факультету ВНМУ ім. М. І. Пирогова, які проходили навчання на кафедрі медичної реабілітації та медико-соціальної експертизи. Серед них були 50 іноземних

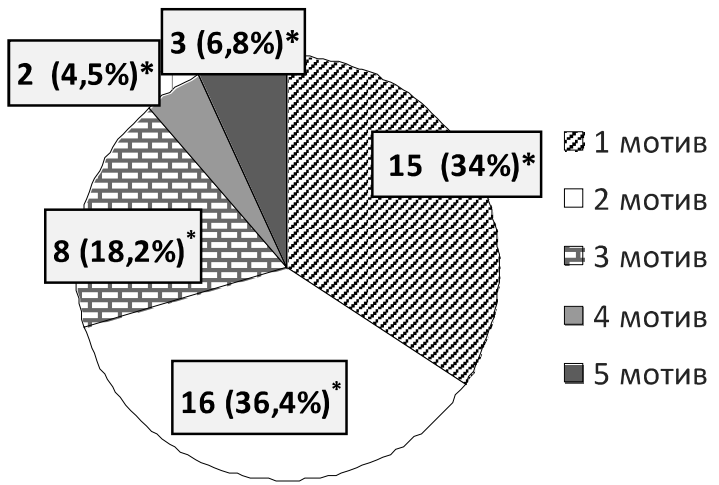

А) Українські студенти $(\mathrm{n}=44)$ (з країн Африки та Індії) та 44 українських студенти. За гендерівською ознакою майбутні медики розподілялися майже порівну ( $<0,5)$, вік респондентів склав від 21 до 34 років.

Дизайн дослідження передбачав використання психодіагностичних методик тестування для визначення загальних мотивів навчальної діяльності у модифікації А. О. Реана та В. О. Якуніна [1, $3,13]$. Обробка даних проводилася за програмою STATISTICA 6,0, різниця результатів визнавалася достовірною при $\mathrm{p}<0,05$.

Результати дослідження. Перше завдання включало вибір студентом 5 найбільш вагомих варіантів загальних мотивів до навчання серед 16 запропонованих прикладів [1, 3]. Так, в обох групах респондентів частіше всього були обрані однакові мотиви, представлені нижче, однак з різною частотою. Варіант першого мотиву свідчив, що головне у навчанні - стати висококваліфікованим спеціалістом, другий - набути глибоких знань у медицині, третій забезпечити успішність майбутньої професійної діяльності, четвертий - отримати інтелектуальне задоволення від навчання, п’ятий - відмінно навчатися, складати іспити на добре та відмінно (рис. 1).

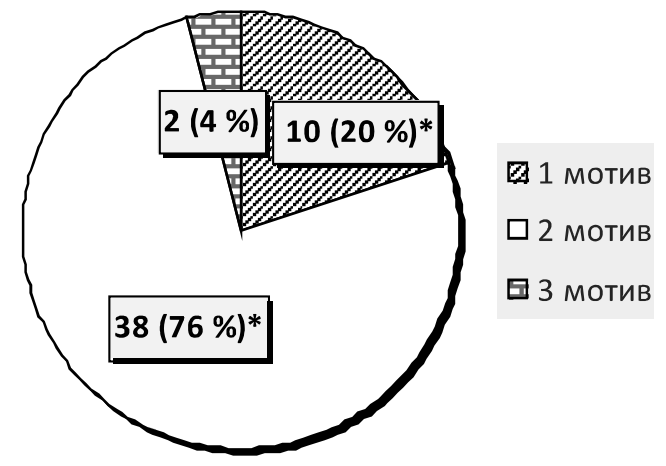

Б) Іноземні студенти $(\mathrm{n}=50)$

Рис. 1. Розподіл мотивів до навчання згідно з відповідями респондентів на опитувальник А. О. Реана та В. О. Якуніна (n=94).

Примітки: 1. * - різниця за мотивами 1, 2, 3, 5 між українськими та іноземними студентами достовірна (p<0,05 \%). 2. Кількість іноземних студентів, які обрали мотиви 4 та 5, дорівнювала 0.

Аналіз отриманих відповідей дозволив порівняти частоту, з якою студенти вказували те, що спонукає до навчання. Так, у студентів з України найбільш вагомими були перші дві причини одержання знань, проте в іноземних студентів - тільки друга. Можливість мати інтелектуальне задоволення від навчання та одержувати високі бали на іспитах за «шкільною звичкою» найменшою мірою сприяють мотивації українських студентів та взагалі не мотивують іноземних студентів. Слід відмітити, що більшість респондентів з країн Африки та Індії добре розуміє перспективи майбутньої професії та їх успішність напряму залежить від знань, які здобудуть. Досить часто студенти, які приїжджають на навчання до України, вже мають певний досвід роботи або навіть вже закінчили непрофільний навчальний заклад, $є$ старшими за віком, тому добре усвідомлюють відповідальність за майбутнє, перш за все, перед собою. 
Мотивація є складним процесом із спонукальними факторами різних напрямків. Зовнішній напрямок мотиваційного процесу залежить від оточення: батьків, викладачів, суспільства. Внутрішня мотивація відображає особистість людини, їі бажання, силу духа, наполегливість. Розвиток особистої мотивації $\epsilon$ найбільш головним та пріоритетним у процесі становлення спеціаліста, а особливо медика $[3,5,7,14]$.
Друга методика психодіагностичного тестування у модифікації А. О. Реана та В. О. Якуніна дозволяє визначити особливості та рівень внутрішньої (особистої) мотивації. Завдання складалось із вибору оцінок «правильно», «не до кінця правильно», «не до кінця неправильно» або «неправильно» по відношенню до себе із запропонованих 20 висловлювань (рис. 2). Підрахунок показників проводився відповідно до ключа психодіагностичних методик $[1,3]$.

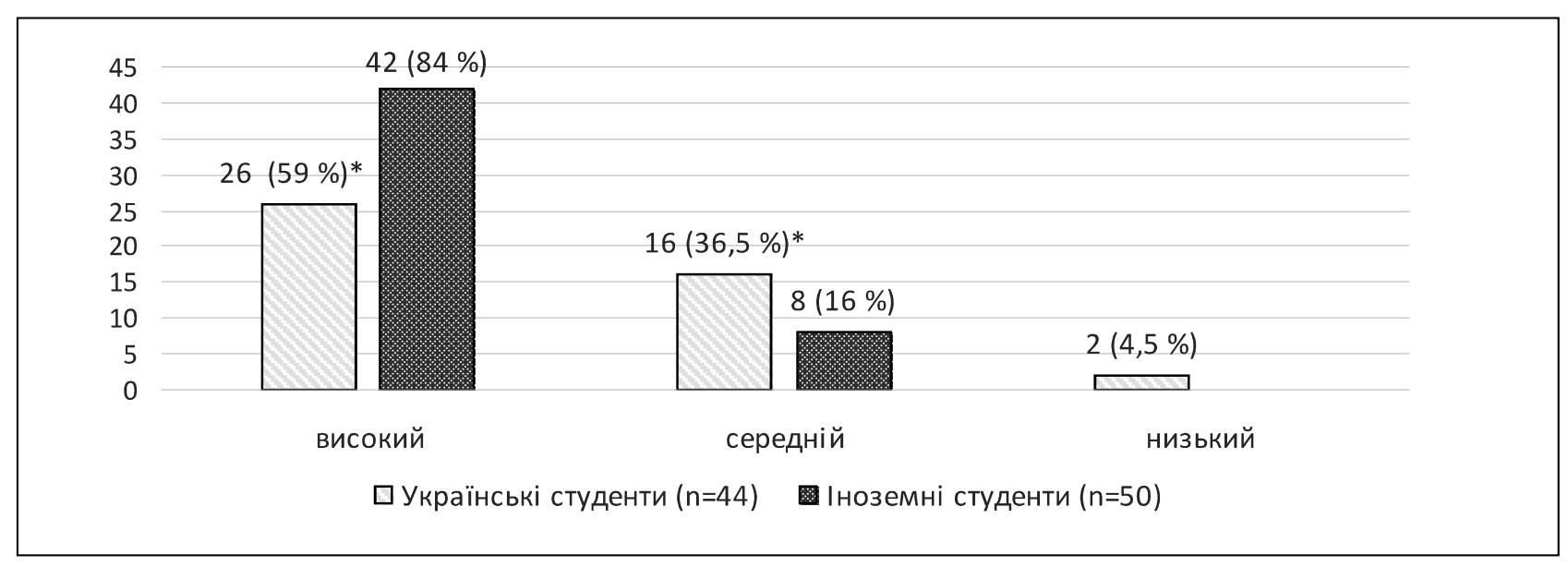

Рис. 2. Розподіл студентів за рівнями мотивацій за методикою А. О. Реана та В. О. Якуніна (n=94). Примітка. * - різниця даних тестів між українськими та іноземними студентами достовірна $(\mathrm{p}<0,05)$.

Інтерпретації даних та статистичний підрахунок показали, що в групах вітчизняних та іноземних студентів внутрішня мотивація знаходиться на середньому та високому рівнях. Однак 4,5 \% українських студентів відповіли, що навчаються у ВНЗ за бажанням батьків та самостійно ще не визначилися з майбутнім і це $є$ прикрим. Переважна більшість студентів з країн Африки та Індії (86 \%) високо мотивовані на навчання та здобуття практичних навичок. Рівень високої мотивованості серед студентів з України достовірно $(\mathrm{p}<0,05)$ поступається $(59 \%)$ іноземним колегам. Відомо, що проблема мотивованості до навчання у закордонних вищих медичних школах та університетах не стоїть взагалі. Це пояснюється тим, що процес зарахування до ВНЗ $€$ досить складним, навчання - дороговартісним і тільки високо мотивовані молоді люди можуть подолати всі перепони та бути відповідальними за справу, яку роблять [1].

Проблема зацікавленості у здобутті знань студентів-медиків в Україні стоїть досить гостро, особливо в період сучасних реформ [7]. Отримані результати тестів $є$ подібними у майбутніх лікарів інших ВН3, що доводить існування проблеми та необхідність пошуку нових рішень [14]. Так, О. П. Венгер та співавт. (2018) і Н. В. Агранович та С. А. Книшева (2015) дослідили динаміку мотиваційних процесів у студентів 2 та 4 курсів різних медичних університетів і відмітили, що динаміка професійного становлення змінюється протягом навчання. Частота високого рівня мотивації у студентів зростає на останніх курсах навчання порівняно з початковими. Отримані нами дані збігаються із колегами, що пояснюється відповідальністю та впевненістю більшості майбутніх лікарів у правильно обраній спеціальності $[1,8]$. Однак порівняльна оцінка мотивованості україномовних та іноземних студентів проведена нами вперше.

Слід визначити, що внутрішня та зовнішня зацікавленість студента є сторонами одного цілого, вони знаходяться у взаємному зв'язку. Підвищення внутрішньої мотивації обов'язково позитивно відображається на зовнішніх мотивах та в кінцевому результаті виховує сильну професійно спрямовану особистість [2]. Вдосконалення вищої медичної освіти за сучасними вимогами неможливе без впровадження в методичний арсенал викладача новітніх педагогічних та інформаційних технологій, нових методів навчання та оригінальних методичних прийомів $[7,16]$. 
Беззаперечно, на етапі студентства одним із ключових моментів у зацікавленості навчанням $\epsilon$ інформація, яку отримує майбутній лікар. Підтвердженням цього стали відповіді вітчизняних та іноземних студентів 5 курсу на анонімну анкету (15 варіантів відповідей). Респондентам було запропоновано обрати негативні фактори мотивації навчального процесу. Серед причин, що не сприяють зацікавленості навчанням, виявилися такі: недостатній рівень використання сучасних технологій у навчальному процесі (56 \%), відсутність достатньої можливості реально відпрацювати практичні навички (72 \%), великий об’єм інформації, необхідний для щоденного опрацювання для підготовки 3-4 різних предметів (62 \%).

Однією з важливих особливостей сучасної людини є сприйняття інформації за допомогою коротких, яскравих посилів, що втілені у форматі постеру, відеокліпу. Досліджена здатність людини швидко переключатися між різними за смислом фрагментами інформації та якісно процесувати її. Відомо, що подача образної, нетекстової інформації прискорює іï засвоєння та дозволяє утримувати в оперативній пам’яті мозку [11]. Мультимедійні презентації можуть бути доречним доповненням як практичних занять, так і лекційного матеріалу [16].

Ще один напрямок використання сучасних технологій - це заснування на базі медичних ВНЗ симуляційних центрів. Симуляційна освіта широко використовується в практичній підготовці медичних фахівців та має доведену ефективність [10]. Завдяки технічним засобам навчання створюються необхідні умови для освоєння та закріплення практичних навичок, коли їх відпрацювання максимально наближене до реальності [2]. Метод симуляції дає майбутньому лікарю можливість спробувати себе у різних ролях, виконуючи завдання професійної діяльності. У студентів формуються навички спілкування з пацієнтом, роботи в команді та відповідальності у прийнятті рішення. Ділова гра «лікар-хворий та хворий - лікар» є ефективним педагогічним інструментом інноваційного навчання, яка направлена на формування клінічного мислення у спеціально створеній проблемній ситуації [2, 10]. Цей підхід дозволяє кожному спробувати себе у різних ролях, сприяє використанню та закріпленню міждисциплінарних зв’язків на практиці, дозволяє відчути відповідальність майбутнього лікаря у прийнятті самостійних рішень $[14,15]$. Як один з інтерактивних методів науково-практичної освіти, симуляційний метод вносить різноманітність у навчальний процес, надає студентам можливість справлятися з реальними ситуаціями, що бувають у професійному житті, тим самим адаптує до трудової діяльності та соціальних контактів [9].

Отже, слід вважати, що напрямками підвищення мотивації до навчального процесу є такі рекомендації:

1. Постійне вдосконалення та оновлення навчального матеріалу.

2. Використання міждисциплінарних зв’язків, що дозволить зрозуміти важливість та практичну необхідність кожного предмета у ВНЗ медичного профілю.

3. Застосування мультимедійних презентацій у практичних та лекційних заняттях.

4. Заняття у симуляційних центрах, впровадження у навчальний процес рольових ігор «хворий-лікар та лікар - хворий» з подальшим обговоренням та визнанням недоліків роботи у кожного учасника.

Висновки та перспективи подальших досліджень. 1. Однією з головних причин високої мотивованості до набуття знань у вітчизняних та іноземних студентів-медиків $є$ перспектива стати кваліфікованим спеціалістом.

2. Внутрішня складова мотивації до навчального процесу у переважної більшості вітчизняних студентів 5 курсу медичного факультету ВНМУ ім. М. І. Пирогова знаходиться на середньому та високому рівнях.

3. Ефективність навчального процесу напряму залежить від різноманітності форм та методів подання науково-практичного матеріалу.

4. Використання новітніх інформаційних технологій, симуляційних центрів сприяє не тільки запам'ятовуванню великого за обсягом теоретичного матеріалу, отриманню практичних та комунікативних навичок, що є необхідним для сучасного лікаря.

Перспективним є продовження пошуку нових форм та методів удосконалення викладання дисциплін, що буде запобігати звиканню до подразників, одноманітності лекцій та практичних семінарів. Необхідне проведення серед студентів моніторування за допомогою психологічних мотиваційних методик, це дозволить ефективно корегувати навчальний процес. 


\section{Список літератури}

1. Агранович Н. В. Изучение мотивации учебной деятельности студентов медицинских вузов и ее роль в формировании готовности к будущей профессии / Н. В. Агранович, С. А. Кнышова // Современные проблемы науки и образования. - 2015. - № 2. - С. 76-78.

2. Баранова I. В. Багаторівневий підхід до викладання медичних дисциплін іноземним студентам на кафедрах клінічного профілю / І. В. Баранова // Медична освіта. 2014. - № 3. - С. 18-22.

3. Єгорова Є. В. Психодіагностичне забезпечення профорієнтації в системі педагогічної освіти : посібник / Є. В. Єгорова, О. М. Ігнатович, В. В. Коробченко ; за ред. О. М. Ігнатович. - Кіровоград : Імекс - ЛТД, 2014. -228 с.

4. Зеер Э. Ф. Психология профессий : учеб. пособие для студентов вузов / Э. Ф. Зеер. - 3-е изд., перераб., доп. - М. : Академический Проспект; Фонд «Мир», 2005. - 336 c.

5. Зливков В. Л. Професійна ідентичність та особистість педагога / В. Л. Зливков. - К. : Здоров’я, 2014. - 131 с.

6. Мерецький В. М. Роль самостійної роботи студентів в організації навчального процесу / В. М. Мерецький // Медична освіта. - 2015. - № 3. - С. 113-115.

7. Мисула I. Р. Досвід викладання англомовним студентам на кафедрі медичної реабілітації за кредитномодульною системою / I. Р. Мисула, О. Я. Зятковська, Т. Г. Бакалюк // Медична освіта. - 2018. - № 1. - С. 9597. - https://doi.org/10.11603/me.2414-5998.2018.1.8837. DOI 10.11603/me.2414-5998.2018.1.8837.

8. Мотивація досягнення як важливий чинник успішного професійного становлення студентів-медиків / О. П. Венгер, Т. П. Гусєва, Ю. І. Мисула, Л. М. Сас // Медична освіта. - 2018. - № 4. - С. 31-35.

9. Мурашкевич А. Організація навчальної діяльності студентів в сучасних умовах розвитку українського

\section{References}

1. Agranovich, N.V. (2015). Izuchenie motivatsii uchebnoy deyatelnosti studentov meditsinskikh vuzov i ee rol $v$ formirovanii gotovnosti $k$ budushchey professii [Studying the motivation of student's learning activities and its role in shaping readiness for the future profession]. Sovremennye problemy nauki i obrazovaniya - Modern Problems of Science and Education, 2 (2), 76-78 [in Russian].

2. Baranova, I.V. (2014). Bahatorivnevyi pidkhid do vykladannia medychnykh dystsyplin inozemnym studentam na kafedrakh klinichnoho profiliu [Multilevel way to teaching of medical subjects for foreing students on the clinical profile departments]. Medychna osvita - Medical Education, 3, 18-22 [in Ukrainian].

3. Yehorova, Ye.V., Ihnatovych, O.M., Korobchenko, V.V., \& Litvinova, N.I. (2014). Psykhodiahnostychne zabezpechennia proforiientatsii $v$ systemi pedahohichnoi osvity [Psychodiagnostic support of vocational guidance in the system of pedagogical education]. Kirovohrad: Imeks LTD [in Ukrainian]. суспільства / А. Мурашкевич // Вісник Київського національного університету ім. Т. Г. Шевченка. - 2011. № 2. - С. 71-74.

10. Перцева Т. О. Інтерактивні технології навчальнопізнавальної діяльності - іноваційні методики змішаного навчання / Т. О. Перцева, Л. І. Конопкіна, Т. В. Кіреєва // Медична освіта. - 2018. - № 4. - С. 73-76.

11. Постовітенко К. П. Використання мультимедійних засобів у викладанні дисципліни «Медична реабілітація» лікарям-інтернам / К. П. Постовітенко // Світ медицини та біології. - 2015. - № 3. - С. 166-169.

12. Прядко Н. О. Мотивація досягнення як детермінанта успіху в професійній діяльності особистості / Н. О. Прядко // Вісник. - 2015. - № 127. - С. 177-180. Режим доступу : http://visnyk.chnpu.edu.ua/?wpfb_ $\mathrm{dl}=1574$.

13. Психологія діяльності та навчальний менеджмент : навч. посіб. / [М. В. Артюшина, Л. М. Журавська, Л. А. Колесніченко та ін.] ; за заг. ред. М. В. Артюшиної. - K. : KHEУ, 2008. - 336 с.

14. Сучасні можливості підвищення мотивації студентів до навчання / Л. В. Беш, Б. Я. Дмитришин, О. М. Беш [та ін.] // Львівський клінічний вісник. 2017. - № 1 (17). - С. 60-64. - http://lkv.biz/wp-content/ uploads/2017/05/Besh-L.-et-al.2017.pdf.

15. Фіра Д. Б. Симуляційне навчання студентів як один із перспективних методів формування та вдосконалення професійних хірургічних навичок у майбутніх лікарів / Д. Б. Фіра // Медична освіта. - 2017. - № 4. - С. 58-60. 16. Хребтій Г. І. Інноваційні технології, направлені на розвиток клінічного мислення у студентів вищих медичних навчальних закладів України / Г. І. Хребтій // Буковинський медичний вісник. - 2015. - Т. 19, № 2. C. 252-255.

4. Zeer, E.F. (2005). Psikhologiya professiy: uchebnoye posobiye dlya studentov vuzov 3-e izd., pererab., dop. [Psychology of professions: a textbook for university students. The 3rd ed. rew.]. Moscow: Akademicheskiy Prospekt; Fond "Mir” [in Russian].

5. Zlyvkov, V.L. (2014). Profesiina identychnist ta osobystist pedahoha [Professional identity and the identity of a teacher]. Kyiv: Znannia [in Ukrainian].

6. Meretskyi, V.M. (2015). Rol samostiinoi roboty studentiv $v$ orhanizatsii navchalnoho protsesu [The role of individual work of students in the organization of educational process]. Medychna osvita - Medical Education, 3, 113-115 [in Ukrainian].

7. Mysula, I.R., Ziatkovska, O.Ya., \& Bakaliuk, T.H. (2018). Dosvid vykladannia anhlomovnym studentam na kafedri medychnoi reabilitatsii za kredytno-modulnoiu systemoiu [Teaching experience for English-speaking students by the credit-transfer system]. Medychna osvita Medical Education, 1, 95-97 [in Ukrainian]. 
8. Venher, O.P., Husieva, T.P., Mysula, Yu.I., \& Sas, L.M. (2018). Motyvatsiia dosiahnennia yak vazhlyvyi tchynnyk uspishnoho professiinoho stanovlennia studentiv-medykiv [Motivation of achivment as an important factor of successful professional development of medical students]. Medychna osvita - Medical Education, 4, 31-35 [in Ukrainian].

9. Murashkevych, A. (2011). Orhanizatsiia navchalnoi diialnosti studentiv $v$ suchasnykh umovakh rozvytku ukrainskoho suspilstva [The organization of educational activity of students in modern conditions of development of Ukrainian society]. Visnyk Kyivskoho natsionalnoho universitetu im. T.H. Shevchenka - Journal of Kyiv National University by T.H. Shevchenko, 2, 71-74 [in Ukrainian].

10. Pertseva, T.O., Konopkina, L.I., \& Kireieva, T.V. (2018). Interaktivni tekhnolohii navchalno-piznavalnoi diialnosti inovatsiini metodyky zmishanoho navchannia [Interactive educational technology innovative methods of combined education]. Medychna osvita - Medical Education, 4, 73-76 [in Ukrainian].

11. Postovitenko, K.P. (2015). Vykorystannia multimediinykh zasobiv u vykladanni dystsypliny "Medychna reabilitatsiia" likariam-internam [Use of multimedia in teaching of "Medical rehabilitation" for interns]. Svit biolohii ta medytsyny - World of Medicine and Biology, 3 (52), 166-169 [in Ukrainian].

12. Priadko, N.O. (2015). Motyvatsiia dosiahnennia yak determinant uspikhu v professiiniii diialnosti osobystosti [Achievment motivation as a determinant of success in person's professional activities]. Visnyk - Herald, 127, 177180. Retrieved from: http://visnyk.chnpu.edu.ua/?wpfb_ $\mathrm{dl}=1574$ [in Ukrainian].
13. Artiushyna, M.V., Zhuravska, L.M., Kolesnichenko, L.A., Kotykova, O.M., \& Radchenko, M.I. (2008). Psykholohiia diialnosti ta navchalnyi menedzhment: navch. posib. [Psychology of activity and educational management: manual]. Artiushyna M.V. (Ed.). Kyiv: KNEU [in Ukrainian].

14. Besh, L.V., Dmytryshyn, B.Ya., Besh, O.M., Yaskevych, O.I., \& Matsiura, O.I. (2017). Suchasni mozhlyvosti pidvyshchennia motyvatsii studentiv do navchannia [Modern possibilities of increasing the motivation of students to study]. Lvivskyi klinichnyi visnyk - Lviv Clinical Herald, 1 (17), 60-64. Retrieved from: http:// lkv.biz/wp-content/uploads/2017/05/Besh-L.-et-al.2017.pdf [in Ukrainian].

15. Fira, D.B. (2017). Symuliatsiine navchannia studentiv yak odyn iz perspektyvnykh metodiv formuvannia ta vdoskonalennia profesiiinykh khirurhichnykh navychok u maiibutnikh likariv [Simulation teaching of students as one of promising techniques of future doctors' professional skills in surgery formation and improvement]. Medychna osvitaMedical Education, 4, 58-60 [in Ukrainian].

16. Khrebtii, H.I. (2015). Innovatsiini tekhnolohii, napravleni na rozvytok klinicnoho myslennia u studentiv vyshchykh medycnykh navchalnykh zakladiv Ukrainy [Innovative technologies aimed at the development of clinical thinking among students of higher medical educational institutions of Ukraine]. Bukovynskyi medycnyi visnyk - Bukovyna Medical Journal, 9, 2, 252-255 [in Ukrainian]. 